\title{
The significant correlation between self-efficacy and goal orientation with the role of Islamic education teachers as a society change agent
}

\author{
Noornajihan Jaafar (Assoc. Professor) ${ }^{1}$, Nurul Asia Fasehah Muhamad (PhD) ${ }^{2}$, \\ Ab. Halim Tamuri (Professor) ${ }^{3}$, Nur Hanani Hussin (PhD) ${ }^{4}$ \\ ${ }^{1}$ Assoc. Prof. Islamic Science Unversity of Malaysia \\ ${ }^{2}$ Senior Lecturer, Islamic Science Unversity of Malaysia \\ ${ }^{3}$ Rector, International College University of Selangor, Malaysia \\ ${ }^{4}$ Assistant Director, Fundamental Research Unit, $M O E$ \\ DOI: https://doi.org/10.37134/jrpptte.vo19.no2.3.2019
}

Received: 09 June 2017; Accepted: 01 November 2019; Published: 30 November 2019

\begin{abstract}
The role of Islamic education teacher (IET) as society change agent (SCA) requires a strong internal motivation factor. It begins with confidence in self-ability, which is selfefficacy (SE) in implementing the trust given to them. In addition, goal orientation (GO) is also important in ensuring that the effort is successful. The study aims to assess the relationship between SE and GO of IET in Malaysia with the role of SCA in society. This study aims to assess the relationship between SE ITE in Malaysia with the role of SCA in society. This quantitative study has involved 1382 IETs in Malaysia. The sampling technique used was cluster sampling and based on random sample selection. The findings show that the SE level of ITE is at high level. Same goes to the GO, the perception of IET toward their GO is in good level. But the role of IET as SCA is at less satisfactory level. Furthermore, SE and GO have been identified to have significant correlation with IET's role as SCA but was at low and weak level. The implication is, the study finds that the focus should be on restoring IET's mindset about the community's work and developing the ummah, as well as the 21 st century teaching and learning (T\&L) skills. In fact, IET needs to be given practical exposure to engage in society through NGOs, surau, mosques, da'wah organization and government agencies.
\end{abstract}

Keywords: self-efficacy, goal orientation, Islamic education teacher, society change agent

\section{INTRODUCTION}

The vital role of teachers in strengthening and promoting education in the country is undeniable. In addition to shouldering the enormous trust and responsibility to ensure the goals of Islamic education can be achieved, the role of teachers in society, especially IET, should be appreciated. This is because these educated personalities have an influential position that can bring about changes in society through the aspect of strengthening religion which is a value system that needs to be understood, appreciated and practiced. The role of the teacher as SCA can be realized through its function as a means of knowledge presenter, mind and personality formulator. In producing a future generation with high cognitive ability, full of pure values and strong faith and stand in religion, teachers need to act as a driving force for the transformation of national education.

The era of globalization, the borderless world is witnessing the increasingly challenging role of teachers. The burden of teachers is increasingly heavy and requires great patience and accountability (Abdullah, 2011; Mohd Kamal, 2011; Kagwiria \& Amukowa, 2013). Not to mention in this case is IET. In fact, IET's responsibilities are seen as bigger as the ustaz and ustazah titles bear the role of preachers (Ab. Halim, 2012; Ahmad Kilani, 2005; Asmawati, 2005). Even the challenge of providing quality teachers is a global issue that concerns educational policy makers in every country (Corcoran, 2007; Darling-Hammond et al., 2009)

*Email: noornajihan@usim.edu.my 
Issues such as moral collapse among adolescents cause IET to struggle in shouldering the trust given to them. IET is also faced with the challenges of booming information technology. Programs shown in electronic media or print media become favorite among teenagers today. This somewhat affects young people's thinking, attitudes and behavior. Therefore, teachers especially ITEs are advised to play a wider role not only in schools but also as SCAs in society (Bourn, 2018; Calvo, 2017). The SCA is a person who helps carry out any social change or organized innovation (Rimal, 2018) other than able to work with other individuals, groups and communities to improve the quality of life (Nnebedum, 2019). Narey (2019) said that effective SCA features are catalysts of change, problem solvers, resourcelinkers and process helper.

The children's education, which was originally under the responsibilities of the family, has now been largely taken over by teachers, especially IET in educating the younger generation (Ab. Halim, 2011). The willingness of teachers to face the challenges of responsibility and the current student scenario is indirectly influenced by the teacher's belief in the capability and ability to carry out such responsibilities (Casey, 2011; Coady et al., 2011) and also the goal orientation of that particular teacher (Butler, 2007; Runhaar et al., 2010).

The role of IET as a SCA should be appreciated by educators in dealing with the behavior of students in this century. This is because, in order to form a holistic Muslim generation and balanced in terms of spiritual, emotional, intellectual and physical, an IET is not just conveying knowledge, but also guiding the students. The appreciation of the role of IET as a SCA which can be seen through IET's daily practice. IET requires a form of confidence and believe in themselves to do it (al-Ghazali, n.y). This belief is known as teacher's SE (Bandura, 1997; Gibson \& Dembo, 1984).

SE theory is generally introduced by Bandura (1977), i.e. a person's personal beliefs to carry out an assignment in accordance with predetermined standards. Later this theory was further developed by Ashton (1984) and Gibson \& Dembo (1984) by focusing on teachers' SE. The teachers' SE as highlighted by Ashton (1984) is the measure of teacher's confidence that he or she has an influence on the overall performance of students, not just academics but also student self-formation. Confidence in the strength, capability and self-ability to teach, guide and educate students is the factor that distinguishes between teachers (Gibson \& Dembo, 1984).

Additionally, a clear and consistent goal is needed in the success of an effort. The theory of Edwin Locke in Ucar Yazici Bozkaya (2016) states that individuals who have a clear and consistent goal affect the person's success and satisfaction in responding to him. GO refers to individual perceptions about the reasons that motivated him to do something. In the field of education, goal orientation is often studied to see its role in determining the achievement of students in academia. These variables are also often studied in the field of general occupation but have begun to be expanded to the teachers (Dresel, Fasching, Steuer \& Nitsche, 2013; Ucar \& Yazici Bozkaya, 2016).

IET's quality-related studies have not been carried out that many yet. Among the studies that have been conducted are the study of IET's role based on the concept of "Five Mim" by Ab. Halim et al. (2010a), a study of professionalism level among IET by Ab. Halim et al. (2010b), Sabah IET quality by Mohd Kassim (2010), Excellent IET by Kamarul Azmi (2010), student assessment on ITE professionalism in MRSM by Syed Najmuddin et al. (2009), the quality of IET by Ghazali (2012) and a study on IET as murabbi by Noornajihan Jaafar (2015).

From these studies, non-was found conducted on IET as SCA AP not to mention by connecting it with SE and GO. There are only four studies that touch on the quality of IET in SMK in particular, namely the study of Mohd Kassim (2010) which examines the quality of IET in Sabah and the study of Kamarul Azmi (2010) which examines the quality of Excellent ITE. Both are qualitative. Although Ghazali (2010) study is quantitative, the study examines IET's knowledge, skills and practices based on 19 types of teacher's quality. Similarly, Noornajihan (2015) study, it examines the quality of IET as murabbi by successfully identifying nine major components. The study of Noornajihan (2015) not only examines the quality of IET as murabbi, but also analyzes the relationship of SE and IET's environmental factors towards the quality as murabbi.

While the studies were conducted on GO focusing on assessing the relationship between GO and the proactive behavior of teachers (Zhang et. al, 2016); level of engagement (Han, Yin, \& Wang, 2016); stress (Parker et al., 2012; Skaalvik \& Skaalvik, 2013); teacher's SE (Künsting et al., 2016; Huang. 2016).

Hence, based on the vacuum left by previous studies from 2010 to 2015 as mentioned previously, it is important that this focused study is conducted to identify the SE relationship with the role of IET as SCA in the community. Therefore, this study aims to achieve the following study objectives:

i. $\quad$ identifying the level of SE of IET at secondary national school,

ii. identifying the level of GO of IET at secondary school,

ii. identify the quality level of IET at secondary national school as SCA, and

iii. assessing the relationship between SE and GO with the role of IET at secondary national school as SCA. 
The Implication is, this study will contribute in the aspect of restoration of the IET profession on social duties and development of the ummah, as well as the 21 st century teaching and learning skills (T \& L). In fact, this study will also contribute to the development of teacher's model as SCA in the community with SE and GO as the basis for such quality. In addition, the IET will especially be practically exposed to the engagement in society through NGOs, surau, mosques, da'wah organization and government agencies.

\section{METHODOLOGY OF STUDY}

This is a quantitative study which involve distributing questionnaires to IET. For the purpose of this study, the researcher has chosen to use the five Likert scale as the respondent's response scale to all the statements used in this research instrument. Most of the researches that had been done using the particulars variables, uses the five Likert scale. The Likert scale is suitable for measuring the views given by respondents in a particular space on a regular basis about a practice, perception and attitude (Cohen et al. 2000; Creswell 1998). For the purposes of data analysis, Likert scale scores are normally arranged to show that high scores show the practice, perception and higher frequency (Wiersma 2000). Accordingly, the score given by the respondents for some negatively expressed statements in this research instrument has been re-encoded to indicate the actual score direction for the answers given by the respondents.

This questionnaire was reviewed and validated by five experts in Islamic Education (Noornajihan, 2018). The preliminary results showed that the cronbach alpha level for the reliability of this study was high at 0.917 . While for each construct, it is as follows:

Table 1: Reliability level according to construct

\begin{tabular}{lc}
\hline \multicolumn{1}{c}{ Category } & Cronbach Alpha \\
\hline SE & 0.904 \\
\hline GO & 0.688 \\
\hline Role of IET as SCA & 0.968 \\
\hline
\end{tabular}

Data collection procedures are implemented in collaboration with the Islamic Education Division, State Islamic Education Sector and researchers. In total, 1382 sets of questionnaires were returned and analyzed. Frequency analysis involving the upper, mean and standard deviation was carried out in addition to Pearson's correlation to evaluate the relationship between independent variables.

\section{FINDINGS OF STUDY}

\section{Questionnaire Respondents}

A total of 1382 respondents' profiles were obtained from the survey questionnaire, covering aspects of demographic background such as school and state. The number of respondents according to the state is Selangor, 230 people (16.6\%), Sabah 102 people (7.4\%), Sarawak 146 people (10.6\%), Perak 109 people (7.9\%), Kedah 117 people (8.5\%), Kelantan 169 people (12.2\%) Pahang 139 people (10.1\%), Malacca 152 people (11.0\%), Perlis 156 people (11.3\%), Wilayah Persekutuan Labuan 62 people (4.5\%).

\section{IET's Perception Towards SE Level}

Overall, IET's perception towards SE is at high level ( $\min =3.94$; s.d $=0.414)$. Table 1 is the details of the items in the SE construct. 
Table 1: Self-Effect Analysis

\begin{tabular}{|c|c|c|c|c|c|c|c|c|}
\hline \multirow{2}{*}{ Code } & \multirow{2}{*}{ Item } & \multicolumn{5}{|c|}{$\begin{array}{l}\text { Percentage (Frequency) } \\
(\mathbf{N = 1 3 6 9 )}\end{array}$} & \multicolumn{2}{|c|}{$\begin{array}{l}\text { Mean and } \\
\text { Standard } \\
\text { deviation }\end{array}$} \\
\hline & & SDN & DN & LB & B & SB & Mean & SD \\
\hline B1 & $\begin{array}{l}\text { Able to achieve most of the goals I have } \\
\text { set. }\end{array}$ & $\begin{array}{l}0.4 \\
(5)\end{array}$ & $\begin{array}{l}0.7 \\
(10)\end{array}$ & $\begin{array}{c}8.8 \\
(122)\end{array}$ & $\begin{array}{c}75.4 \\
(1042)\end{array}$ & $\begin{array}{l}13.5 \\
(186)\end{array}$ & 4.02 & 0.53 \\
\hline B2 & Able to finish a difficult task & $\begin{array}{l}0.3 \\
(4)\end{array}$ & $\begin{array}{c}0.9 \\
(13)\end{array}$ & $\begin{array}{l}14.0 \\
(194)\end{array}$ & $\begin{array}{c}74.4 \\
(1028)\end{array}$ & $\begin{array}{c}9.3 \\
(129)\end{array}$ & 3.92 & 0.54 \\
\hline B3 & $\begin{array}{l}\text { Able to obtain the important result for } \\
\text { me. }\end{array}$ & $\begin{array}{l}0.4 \\
(5)\end{array}$ & $\begin{array}{l}0.3 \\
(4)\end{array}$ & $\begin{array}{l}7.8 \\
(108)\end{array}$ & $\begin{array}{c}79.1 \\
(1093)\end{array}$ & $\begin{array}{l}11.1 \\
(153)\end{array}$ & 4.01 & 0.48 \\
\hline B4 & $\begin{array}{l}\text { Able to succeed with the effort I have set } \\
\text { in my mind. }\end{array}$ & $\begin{array}{l}0.4 \\
(6)\end{array}$ & $\begin{array}{c}0.8 \\
(11)\end{array}$ & $\begin{array}{c}8.4 \\
(116)\end{array}$ & $\begin{array}{c}76.0 \\
(1050)\end{array}$ & $\begin{array}{c}13.2 \\
(183)\end{array}$ & 4.01 & 0.53 \\
\hline B5 & Able to overcome various challenges & $\begin{array}{l}0.3 \\
(4)\end{array}$ & $\begin{array}{l}0.4 \\
(6)\end{array}$ & $\begin{array}{c}10.9 \\
(151)\end{array}$ & $\begin{array}{c}74.0 \\
(1023)\end{array}$ & $\begin{array}{c}12.7 \\
(176)\end{array}$ & 4.00 & 0.53 \\
\hline B6 & $\begin{array}{l}\text { Able to implement different task } \\
\text { effectively }\end{array}$ & $\begin{array}{l}0.1 \\
(2)\end{array}$ & $\begin{array}{l}0.6 \\
(8)\end{array}$ & $\begin{array}{c}14.0 \\
(193)\end{array}$ & $\begin{array}{c}73.2 \\
(1011)\end{array}$ & $\begin{array}{c}11.0 \\
(152)\end{array}$ & 3.95 & 0.53 \\
\hline B7 & $\begin{array}{l}\text { Able to do most of the tasks very well } \\
\text { compared to other people }\end{array}$ & $\begin{array}{l}0.9 \\
(12)\end{array}$ & $\begin{array}{l}1.8 \\
(25)\end{array}$ & $\begin{array}{l}30.0 \\
(415)\end{array}$ & $\begin{array}{c}59.5 \\
(822)\end{array}$ & $\begin{array}{l}6.8 \\
(94)\end{array}$ & 3.70 & 0.66 \\
\hline B8 & $\begin{array}{l}\text { Able to do something fairly well even- } \\
\text { though it is difficult }\end{array}$ & $\begin{array}{l}0.2 \\
(3)\end{array}$ & $\begin{array}{c}0.7 \\
(10)\end{array}$ & $\begin{array}{l}13.1 \\
(181)\end{array}$ & $\begin{array}{c}75.5 \\
(1043)\end{array}$ & $\begin{array}{c}9.5 \\
(131)\end{array}$ & 3.94 & 0.52 \\
\hline
\end{tabular}

* $\mathrm{SNB}=$ strongly don't believe, $\mathrm{DB}=$ don't believe, $\mathrm{LB}=$ less believe, $\mathrm{B}=$ believe, $\mathrm{SB}=$ strongly believe

Overall, the mean score of interpretation value which can be seen based on table 4.10 has shown that IET perception of SE is high starting with item B1 (mean $=4.02$; $\mathrm{sd}=0.536)$ as item having the highest mean score and followed by item B4 (mean $=4.01 ; \mathrm{sd}=0.485)$, B5 (Mean = 4.00; sd =0.533), B6 $(\min =3.95 ; \mathrm{sd}=0.535)$, B8 $($ mean $=3.94 ; \mathrm{sd}=0.523), \mathrm{B} 2(\mathrm{mean}=3.92 ; \mathrm{sd}=0.543)$, and ends with item $\mathrm{B} 7$ which has the lowest mean score i.e. $($ mean $=3.70 ; \mathrm{sd}=0.660$ )

\section{Perceptions of ITE on Goal Orientation Level}

In general, the perception of IET toward GO is in good level with the mean score interpretation of 3.56 and the standard deviation value of 0.267 . However, there are two sub constructs that are in good level and one sub construct which is at satisfactory level. Table 2 shows the mean score and the standard deviation value for the three sub constructs below the GO level construct.

In general, the highest mean score is the mean score for the learning orientation sub construct with the value of 4.07 and the standard deviation value of 0.43 while the second highest mean score is the mean score of the achievement orientation sub construct with the value of 3.74 and the standard deviation value of 0.38 and achieving good level. Sub constructs which reach the moderate level with the lowest mean score are avoidance orientation sub construct which has a mean score of 2.78 and the standard deviation value of 0.46 . All mean score scores and values of these standard deviations have resulted in the mean score of the goal orientation level to achieve good levels although there is one sub construct that reaches only moderate level.

Table 2: Goal Orientation Analysis

\begin{tabular}{clcc}
\hline Code & \multicolumn{1}{c}{ Item } & Mean & SD \\
\hline C1 & Goal Orientation & 3.74 & 0.38 \\
\hline C2 & Avoidance Orientataion & 2.78 & 0.46 \\
\hline C3 & Learning Orientation & 4.07 & 0.43 \\
\hline
\end{tabular}




$\begin{array}{lll}\text { Overall } & 3.56 & 0.26\end{array}$

\section{IET'S Perception Towards The Role As SCA}

Overall, the role of ITE as SCA in society is at satisfactory level (mean $=3.32$; sd $=0.773$ ). However, the findings of the descriptive analysis presented in Table 3 do not show all items achieving a satisfactory mean score and one item even achieves unsatisfactory mean score and some items which achieve a good score.

Based on the table, mean score interpretation shows that 10 items are in good level with the item sequence of $\mathrm{C} 2, \mathrm{C} 3, \mathrm{C} 4, \mathrm{C} 9, \mathrm{C} 8, \mathrm{C} 1, \mathrm{C} 7, \mathrm{C} 12, \mathrm{C} 5$ and $\mathrm{C} 23$. Analysis findings also show that 13 items in this construct are at satisfactory level with the sequence of item C10, C6, C13, C20, C15, C16, C22, C24, C21, C19, C17 and C18. Analysis also shows an item at an unsatisfactory level i.e. item $\mathrm{C} 11$.

Overall, this finding demonstrates that, the role of IET as a community SCA through the items stated in the questionnaire is only at satisfactory level even though there are some items that achieve good mean score. This proves that many ITEs are still lacking in playing their role as an educator outside school area, especially in the community.

Table 3: Analysis of the Role of IET as SCA

\begin{tabular}{|c|c|c|c|c|c|c|c|c|}
\hline \multirow[t]{2}{*}{ Code } & \multirow[t]{2}{*}{ Item } & \multicolumn{5}{|c|}{$\begin{array}{l}\text { Percentage (Frequency) } \\
\text { (N=1370) }\end{array}$} & \multicolumn{2}{|c|}{$\begin{array}{l}\text { Mean and } \\
\text { Standard } \\
\text { Deviation }\end{array}$} \\
\hline & & EL & $\mathbf{L}$ & $\mathbf{M}$ & H & EH & Mean & SD \\
\hline C1 & Spiritual guidance & $\begin{array}{c}1.4 \\
(20)\end{array}$ & $\begin{array}{c}13.2 \\
(182)\end{array}$ & $\begin{array}{l}21.1 \\
(291)\end{array}$ & $\begin{array}{l}44.9 \\
(621)\end{array}$ & $\begin{array}{l}18.2 \\
(252)\end{array}$ & 3.66 & 0.97 \\
\hline $\mathrm{C2}$ & Living according to syariat. & $\begin{array}{c}0.7 \\
(10)\end{array}$ & $\begin{array}{l}6.7 \\
(92)\end{array}$ & $\begin{array}{l}17.6 \\
(243)\end{array}$ & $\begin{array}{l}48.4 \\
(669)\end{array}$ & $\begin{array}{c}25.4 \\
(351)\end{array}$ & 3.92 & 0.87 \\
\hline C3 & Lecture/advice. & $\begin{array}{c}0.7 \\
(10)\end{array}$ & $\begin{array}{c}7.8 \\
(108)\end{array}$ & $\begin{array}{l}18.0 \\
(249)\end{array}$ & $\begin{array}{l}47.7 \\
(659)\end{array}$ & $\begin{array}{r}24.6 \\
(340)\end{array}$ & 3.88 & 0.89 \\
\hline C4 & $\begin{array}{l}\text { Awareness about issue and current } \\
\text { challenges based on the stand of Ahli } \\
\text { Sunah Waljamaah. }\end{array}$ & $\begin{array}{c}2.2 \\
(30)\end{array}$ & $\begin{array}{l}10.6 \\
(147)\end{array}$ & $\begin{array}{l}18.7 \\
(259)\end{array}$ & $\begin{array}{l}45.9 \\
(635)\end{array}$ & $\begin{array}{l}21.3 \\
(294)\end{array}$ & 3.74 & 0.98 \\
\hline C5 & $\begin{array}{l}\text { Involvement in community activities } \\
\text { at surau/mosque. }\end{array}$ & $\begin{array}{c}1.4 \\
(19)\end{array}$ & $\begin{array}{c}20.8 \\
(288)\end{array}$ & $\begin{array}{c}25.0 \\
(346)\end{array}$ & $\begin{array}{c}35.6 \\
(492)\end{array}$ & $\begin{array}{l}16.1 \\
(222)\end{array}$ & 3.44 & 1.03 \\
\hline C6 & $\begin{array}{l}\text { Well verse in various field of } \\
\text { knowledge to solve problem in the } \\
\text { community. }\end{array}$ & $\begin{array}{l}2.0 \\
(28)\end{array}$ & $\begin{array}{l}19.8 \\
(273)\end{array}$ & $\begin{array}{l}27.4 \\
(379)\end{array}$ & $\begin{array}{l}36.8 \\
(509)\end{array}$ & $\begin{array}{c}12.7 \\
(176)\end{array}$ & 3.38 & 1.00 \\
\hline C7 & $\begin{array}{l}\text { The use new media to increase } \\
\text { religious knowledge. }\end{array}$ & $\begin{array}{l}1.5 \\
(21)\end{array}$ & $\begin{array}{c}9.5 \\
(131)\end{array}$ & $\begin{array}{c}27.2 \\
(376)\end{array}$ & $\begin{array}{l}46.8 \\
(647)\end{array}$ & $\begin{array}{c}13.7 \\
(190)\end{array}$ & 3.62 & 0.89 \\
\hline C8 & $\begin{array}{l}\text { Learning plan which is suitable with } \\
\text { the audience (mad'u). }\end{array}$ & $\begin{array}{l}1.5 \\
(21)\end{array}$ & $\begin{array}{l}8.8 \\
(121)\end{array}$ & $\begin{array}{c}24.6 \\
(340)\end{array}$ & $\begin{array}{l}47.8 \\
(661)\end{array}$ & $\begin{array}{l}16.3 \\
(225)\end{array}$ & 3.69 & 0.90 \\
\hline C9 & $\begin{array}{l}\text { Leaning preparation which is suitable } \\
\text { to the audience (mad'u). }\end{array}$ & $\begin{array}{l}1.5 \\
(21)\end{array}$ & $\begin{array}{c}8.8 \\
(122)\end{array}$ & $\begin{array}{c}23.2 \\
(320)\end{array}$ & $\begin{array}{l}49.1 \\
(679)\end{array}$ & $\begin{array}{l}16.2 \\
(224)\end{array}$ & 3.70 & 0.89 \\
\hline C10 & Expert in religious field & $\begin{array}{l}2.6 \\
(36)\end{array}$ & $\begin{array}{c}14.4 \\
(199)\end{array}$ & $\begin{array}{l}29.8 \\
(412)\end{array}$ & $\begin{array}{l}41.1 \\
(568)\end{array}$ & $\begin{array}{c}9.0 \\
(124)\end{array}$ & 3.40 & 0.94 \\
\hline C11 & $\begin{array}{l}\text { Writing (eg: magazine, news-paper, } \\
\text { paper work and journal) }\end{array}$ & $\begin{array}{l}24.1 \\
(333)\end{array}$ & $\begin{array}{l}27.4 \\
(378)\end{array}$ & $\begin{array}{l}21.6 \\
(298)\end{array}$ & $\begin{array}{l}20.8 \\
(287)\end{array}$ & $\begin{array}{c}4.4 \\
(61)\end{array}$ & 2.53 & 1.19 \\
\hline C12 & Spreading knowledge & $\begin{array}{l}1.7 \\
(23)\end{array}$ & $\begin{array}{l}13.0 \\
(179)\end{array}$ & $\begin{array}{l}27.7 \\
(383)\end{array}$ & $\begin{array}{l}42.6 \\
(589)\end{array}$ & $\begin{array}{l}12.5 \\
(173)\end{array}$ & 3.52 & 0.93 \\
\hline
\end{tabular}




\begin{tabular}{|c|c|c|c|c|c|c|c|c|}
\hline C13 & $\begin{array}{l}\text { New Media (social media such as } \\
\text { Facebook, Twitter dan blog). }\end{array}$ & $\begin{array}{c}5.8 \\
(80)\end{array}$ & $\begin{array}{l}16.4 \\
(226)\end{array}$ & $\begin{array}{l}28.9 \\
(400)\end{array}$ & $\begin{array}{l}37.6 \\
(519)\end{array}$ & $\begin{array}{c}9.1 \\
(126)\end{array}$ & 3.28 & 1.03 \\
\hline C14 & $\begin{array}{l}\text { Active self-involvement in volunteer } \\
\text { activities }\end{array}$ & $\begin{array}{l}6.9 \\
(96)\end{array}$ & $\begin{array}{l}30.6 \\
(423)\end{array}$ & $\begin{array}{l}26.8 \\
(371)\end{array}$ & $\begin{array}{l}27.1 \\
(375)\end{array}$ & $\begin{array}{l}6.8 \\
(94)\end{array}$ & 2.96 & 1.07 \\
\hline C15 & Self-involvement in welfare activities & $\begin{array}{c}2.7 \\
(37)\end{array}$ & $\begin{array}{l}24.3 \\
(336)\end{array}$ & $\begin{array}{l}28.9 \\
(399)\end{array}$ & $\begin{array}{l}34.8 \\
(481)\end{array}$ & $\begin{array}{c}7.6 \\
(105)\end{array}$ & 3.20 & 0.98 \\
\hline C16 & $\begin{array}{l}\text { Self-involvement in sports and } \\
\text { recreational activities. }\end{array}$ & $\begin{array}{c}3.8 \\
(53)\end{array}$ & $\begin{array}{l}25.0 \\
(346)\end{array}$ & $\begin{array}{l}30.0 \\
(415)\end{array}$ & $\begin{array}{l}31.3 \\
(432)\end{array}$ & $\begin{array}{c}7.5 \\
(103)\end{array}$ & 3.13 & 1.01 \\
\hline C17 & $\begin{array}{l}\text { Involvement as committee in my } \\
\text { Residential societies and associations }\end{array}$ & $\begin{array}{l}11.3 \\
(156)\end{array}$ & $\begin{array}{l}25.9 \\
(358)\end{array}$ & $\begin{array}{l}26.7 \\
(369)\end{array}$ & $\begin{array}{l}28.6 \\
(395)\end{array}$ & $\begin{array}{c}6.2 \\
(85)\end{array}$ & 2.92 & 1.12 \\
\hline C18 & $\begin{array}{l}\text { Role as representative/mediator to } \\
\text { local community to solve issues which } \\
\text { arise. }\end{array}$ & $\begin{array}{l}16.8 \\
(232)\end{array}$ & $\begin{array}{l}31.0 \\
(429)\end{array}$ & $\begin{array}{l}21.4 \\
(296)\end{array}$ & $\begin{array}{l}24.7 \\
(341)\end{array}$ & $\begin{array}{l}4.3 \\
(60)\end{array}$ & 2.68 & 1.15 \\
\hline C19 & $\begin{array}{l}\text { Development of communication } \\
\text { network with various parties }\end{array}$ & $\begin{array}{c}8.6 \\
(119)\end{array}$ & $\begin{array}{l}26.4 \\
(365)\end{array}$ & $\begin{array}{l}27.0 \\
(373)\end{array}$ & $\begin{array}{c}30.4 \\
(420)\end{array}$ & $\begin{array}{c}6.0 \\
(83)\end{array}$ & 2.98 & 1.08 \\
\hline $\mathrm{C20}$ & $\begin{array}{l}\text { Practicing open attitude in handling } \\
\text { social issues. }\end{array}$ & $\begin{array}{c}5.2 \\
(72)\end{array}$ & $\begin{array}{l}16.4 \\
(226)\end{array}$ & $\begin{array}{c}31.1 \\
(430)\end{array}$ & $\begin{array}{l}38.0 \\
(525)\end{array}$ & $\begin{array}{l}7.7 \\
(107)\end{array}$ & 3.27 & 1.00 \\
\hline C21 & $\begin{array}{l}\text { Practicing open attitude in handling } \\
\text { political issues. }\end{array}$ & $\begin{array}{c}9.6 \\
(132)\end{array}$ & $\begin{array}{l}20.0 \\
(276)\end{array}$ & $\begin{array}{l}29.7 \\
(411)\end{array}$ & $\begin{array}{r}32.6 \\
(450) \\
\end{array}$ & $\begin{array}{c}6.5 \\
(90)\end{array}$ & 3.06 & 1.08 \\
\hline $\mathrm{C} 22$ & $\begin{array}{l}\text { Continuous motivation towards } \\
\text { economic growth. }\end{array}$ & $\begin{array}{c}7.4 \\
(102)\end{array}$ & $\begin{array}{l}21.0 \\
(290)\end{array}$ & $\begin{array}{l}27.7 \\
(383)\end{array}$ & $\begin{array}{l}35.2 \\
(486)\end{array}$ & $\begin{array}{l}6.8 \\
(94)\end{array}$ & 3.13 & 1.06 \\
\hline $\mathrm{C23}$ & $\begin{array}{l}\text { Problem solving in matters relating to } \\
\text { Islam. }\end{array}$ & $\begin{array}{c}2.7 \\
(38)\end{array}$ & $\begin{array}{l}15.7 \\
(217)\end{array}$ & $\begin{array}{c}25.3 \\
(349)\end{array}$ & $\begin{array}{l}43.9 \\
(607)\end{array}$ & $\begin{array}{c}10.3 \\
(142)\end{array}$ & $\begin{array}{c}3.442 \\
0\end{array}$ & $\begin{array}{c}.9728 \\
9\end{array}$ \\
\hline C24 & $\begin{array}{l}\text { Offering best alternative to solve } \\
\text { problems in the community }\end{array}$ & $\begin{array}{c}8.6 \\
(119)\end{array}$ & $\begin{array}{l}21.5 \\
(297)\end{array}$ & $\begin{array}{l}26.0 \\
(360)\end{array}$ & $\begin{array}{l}33.8 \\
(467)\end{array}$ & $\begin{array}{c}8.1 \\
(112)\end{array}$ & 3.11 & 1.11 \\
\hline
\end{tabular}

$* \mathrm{VL}=$ very low, $\mathrm{L}=$ low, $\mathrm{M}=$ moderate, $\mathrm{H}=$ high, $\mathrm{VH}=$ very high

\section{Relationship Between SE and GO with the Role of IET as SCA}

The Pearson correlation analysis was carried out to examine the relationship between the variables studied. Table 4 shows a significant positive relationship between SE with the role of IET as SCA $(r=.386 . s i g=.000)$. Like-wise for $\mathrm{GO}$, in general, findings show that it has a significant relationship though at a low level $(\mathrm{r}=.228$, sig $=.000)$. Specifically, GO learning alone has a significant positive relationship with the role of ITE as TA although weak $(\mathrm{r}=$ .350 , sig $=.000$ ). While GO achievement and avoidance showed no significant relationship with the role of ITE as TA.

Table 4: The Correlation Between GO and SE with the Role of IET

\begin{tabular}{|l|l|l|l|}
\hline No & \multicolumn{1}{|c|}{ Variables } & R & Significant level \\
\hline 1 & GO and the role of IET & .228 & $.000^{* *}$ \\
\hline 2 & SE and the role of IET & .386 & $.000^{* *}$ \\
\hline 3 & Learning Orientation and the role of IET & $.350^{* *}$ & $.000^{* *}$ \\
\hline 4 & Achievement Orientation and the role of IET & -.001 & .976 \\
\hline 5 & Avoidance Orientation and the role of IET & .039 & .154 \\
\hline
\end{tabular}

\section{DISCUSSION}

Overall, SE IET in Malaysia is at high level of 3.94. Similarly, all items are at high level. This illustrates that IET has a positive SE although it still does not reach a very high level. The high SE is very important as it will affect teachers' teaching practices and their role as SCA through the development of skills (Trentham et al., 1985), acceptance and readiness towards innovation and task challenges (Guskey, 1987), continuous work improvement and improved performance (Bandura, 1977). This can be seen in the four highest items, "able to get results that are important to me"; "able to achieve most of the goals I have set"; "able to succeed with the effort I have set in my mind"; and "able to 
successfully overcome various challenges". SE IET can be enhanced through the development of teacher professionalism, building excellent model teachers, continuous learning, quality and continuous training, collaboration networks with others in either field or non-field.

The findings also showed that the mean of learning orientation among IET was the best i.e. at high level compared to two other orientations. This finding also shows IET has the will to increase knowledge and skills through exposure, training, courses and workshops provided by the parties involved. This finding is in line with the views expressed by teachers who show the high degree of learning orientation to increase the effort towards their professional development (Runhaar et al., 2010). However, IET is currently not getting enough training or courses during their service which hindering their development in line with current challenges. In that regard, IET needs to be provided with space and opportunity to enhance their capabilities and professionalism through courses, training, workshops and seminars based on their high-level learning orientation.

While, the study found that the role of IET as a community TA was at unsatisfactory level because the overall mean was only at moderate level of 3.32. The findings show that no item is at a very high level and this should be given due attention by the Malaysian Ministry of Education. If analyzed more closely, it is found that items with high mean are related to routine tasks or routine tasks which are frequently performed by Islamic education teachers. In general, the role that is being done around self-development, daily tasks as educators and spiritual aspects. Teachers focus more on individual aspects of inner and spiritual development.

For items which are at moderate level, relevant items involve in more challenging and community-based tasks. Among the more challenging responsibilities such as the mastery of various knowledge disciplines to solve community problems, as experts in religious affairs, involvement in welfare activities, addressing social issues and building communication networks with various parties as well as the lack of ability to offer the best alternatives to solving problems in the community. Even their involvement in the community where they reside is also at moderate level and this also exists in inactive involvement in volunteer activities. Two unsatisfactory aspects are the practice of open attitude in addressing political issues as well as providing continuous motivation towards economic growth. One element that seems unsatisfactory is the lack of involvement in sports and leisure activities. IET is also found to be lacking in the use new media or social media such as Facebook, Twitter and blogs in the community. IET also do not play enough role as SCA through writing such as magazines, newspapers, paper works, and journals. In fact, lower items were also identified regarding IET's role as a representative / mediator to the local community to resolve their issues.

Kamarul Azmi (2010), highlighted that the active participation of teachers in community activities such as delivering lectures at mosques or suraus, opening Quran and fardhu ain classes at night and weekends, writing and posting in magazines and various other media is compatible with the characteristics of a murabbi or catalyst. IET as SCA is also in line with the role of murabbi who develops morals not only as a conveyor of knowledge (mu'allim). In short, the teacher should also try to apply manners (discipline in thinking, physical and spiritual) by becoming a muaddib as well as forming an effective teaching character in them (mudarris) and able to lead with guidance (mursyid).

In addition, this study found that there was a significant correlation between SE and the role of IET as SCA. This shows that IETs with high SE have a great role in the society. This finding reinforces the view of Ashton (1984) that the teacher with high SE not only affects academic achievement, but also the formation of good student and the people around them. This is the factor, according to Guskey (1987) that distinguishes the quality of a teacher.

Likewise, the sub construct of GO learning has a significant relationship with the role of IET as a SCA. However, the two other GO sub constructs i.e. GO achievement and GO avoidance, have no significant relationship. This shows that IET who has the desire to learn something new plays the role of SCA in society. This IET has the desire to learn something new though it is difficult, as well as stating they will work harder if they fail to carry out difficult tasks. Additionally, they tend to set a more challenging goal when learning something and always be ready to challenge themselves to learn new concepts. To them, this is an opportunity to develop a variety of abilities that are important because they have the opportunity to learn something new that is very important to them. Teachers who demonstrate high levels of GO learning will spend more effort on their professional development (Runhaar et al., 2010) and have a higher level of self-efficacy (Butler, 2007; Runhaar et al., 2010; Schiefele \& Schaffner, 2015) as well as demonstrating proactive behaviors (Zhang, Law, \& Lin, 2016).

\section{CONCLUSION}

In practice and Prophet Muhammad (pbuh) sirah, the task of teachers should be linked to the task of preachers. In other words, a IET is also a preacher or $d a^{\prime} i$. So, as teachers who act as preachers, their important task is 
to educate the public on Islamic teachings and their implementation in everyday life, especially among their students. The role of IET as the SCA really needs to be paid attention because the role of the teacher is to spread knowledge that can provide noble values to society as well as play a role as a social SCA. Abd Ghafar (2011) considers IET is the earliest SCA in the community based on their role in teaching, educating and guiding as how they have planned. IET must meet the community's demands to become $a$ role model either directly or indirectly as well as having wide and global views and not subject to the scope of the existing responsibilities. This huge role cannot be attributed to the level of self-belive of any individual and GO learning of IET in executing the given trust.

In this regard, the IET who plays the role of SCA needs to have a high SE to initiate the action apart from regarding that external obstacles as not a threat but focusing on the internal. Similarly, with clear GO, it is important to ensure involvement in community activities can be carried out, as well as the task of educating and guiding students as set out in the Islamic Education Philosophy. The importance of GO has been emphasized by the Prophet SAW through his Hadith that every task or job depends on one's intentions. In fact, that person will get what is intended and perceived.

\section{REFERENCES}

Ab. Halim T., Khadijah A.R. \& Shahrin A. (2010). Kaedah pengajaran Pendidikan Islam: konvensional dan inovasi. in. Ab. Halim T. \& Nik Mohd. Rahimi N.Y. (ed) Kaedah Pengajaran Dan Pembelajaran Pendidikan Islam, p. 38-70. Bangi: Universti Kebangsaan Malaysia.

Ab. Halim T., Mohd Aderi C. N., Khadijah A. R., Kamarulzaman A. G. \& Zarin I.. (2010a). Penilaian pelajar-pelajar terhadap amalan pengajaran guru Pendidikan Islam di sekolah-sekolah menengah di Malaysia. Conference paper Serantau Pendidikan Islam 2010. Organized by Kementerian Pelajaran Malaysia, 26 April.

Ab. Halim T.. (2011). Penghayatan Islam Melalui Pengajaran Dan Pembelajaran. Conference paper Kongres Pendidikan Islam Kebangsaan. Organized by Kementerian Pelajaran Malaysia. Dinasty Hotel Kuala Lumpur, 4-7 Disember.

Ab. Halim T. (2012). The Role of Mosque: The Intergration Approach of Teaching and Learning Process. Anjuran PIMM \& The Islamic Academy Cambridge, United Kingdom, International Conference on Research in Islamic and Arabic Languange Education 2012, Elaf Kinda Hotel, Mecca, Saudi Arabia, 1-2 Jun

Abdullah M. D. (2011). Pendidikan Islam Malaysia: Isu Dan Cabaran. Conference paper Kongres Pendidikan Islam Kebangsaan 2011. Organized by Kementerian Pelajaran Malaysia. Dinasty Hotel Kuala Lumpur, 4-7 Disember.

Ahmad Kilani M.. (2005). Pengurususan Pendidikan Di Sekolah Dari Perspektif Islam. Johor: Universiti Teknologi Malaysia.

Al-Ghazali A. H. (n.y) Ihya' Ulum Al-Din. Kaherah: al-Masyad.

Ashton, P. (1984). Teacher Efficacy: A Motivatioanal Paradigm for Effective Teacher Education. Journal of Teacher Education, 35(5): 28-32.

Asmawati S. (2005). Pemantapan Komponen Akhlak Dalam Pendidikan Islam Bagi Menangani Era Globalisasi. Jurnal Kemanusiaan 6: 95-104.

Bandura, A. (1997). Self Efficacy in Changing Society. New York: Cambridge University Press.

Bourn, D. (2018). The Global Teacher. In Understanding Global Skills for 21st Century Professions. Cham: Palgrave Macmillan. p $163-200$.

Butler, R. (2007). Teachers' achievement goal orientations and associations with teachers' help seeking: Examination of a novel approach to teacher motivation. Journal of Educational Psychology, 99(2), 241-252.

Calvo, A. (2017). The state of development education in Spain: Initiatives, trends and challenges. International Journal of Development Education and Global Learning, 9(1), 18-32.

Casey, M. (2011). Perceived Efficacy and Preparedness of Beginning Teachers to Differentiate Instruction. Tesis PhD, Faculty of Leadership, Johnson \& Wales University.

Coady, M., Harper, C. \& De Jong, E. (2011). From Preservice to Practice: Mainstream Elementary Teacher Beliefs of Preparation and Efficacy with English Language Learners in the State of Florida. Bilingual Research Journal 34(2): 223-239.

Cohen, J. W. (1988). Statical Power Analysis for the Behavioral Sciences. Edisi Ke-2. Hillsdale, NJ: Lawrence Erlbaum Associates.

Corcoran, T. B. (2007). Teaching Matters: How State and Local Policymakers Can Improve the Quality of Teachers and Teaching. Philadelphia, PA: Consortium for Policy Research in Education, University of Pennsylvania.

Creswell, J. W. (1998). Qualitative Inquiry and Research Design: Choosing among Five Traditions. New Jersey: Pearson Education Ins.

Darling-Hammond, L., Wei, R. C., Andree, A., Richardson, N. \& Orphanos, S. (2009). Professional Learning in the Learning Profession: A Status Report on Teacher Development in the United States and Abroad. Washington, DC: National Staff Development Council.

Dresel, Fasching, Steuer \& Nitsche. (2013). Relations between Teachers' Goal Orientations, Their Instructional Practices and Students' Motivation. Psychology, 4(7): 572-584.

Ghazali D. (2012). Kualiti Guru Pendidikan Islam di Malaysia. Research Report. Universiti Malaya, Kuala Lumpur. 
Gibson, S. \& Dembo, M. H. (1984). Teacher Efficacy: A Construct Validation. Jurnal of Educational Psyhology 76(4): 569-582.

Han, Yin \& Wang. (2016). The Effect Of Tertiary Teachers' Goal Orientations For Teaching On Their Commitment: The Mediating Role Of Teacher Engagement. Educational Psychology, 36(3).

Huang, C. (2016). Achievement goals and self-efficacy: A meta-analysis. Educational Research Review, 19, 119-137.

Kagwiria, K., \& Amukowa, W. (2013). Teacher's Productivity in Promoting Quality Education in Public Primary Schools in Kenya. Academic Journal Of Interdisciplinary Studies, 2(2), 365.

Kamarul A. J. (2010). Guru Cemerlang Pendidikan Islam Sekolah Menengah Di Malaysia: Satu Kajian Kes. Thesis. PhD. Universiti Kebangsaan Malaysia.

Künsting, J., Neuber, V., \& Lipowsky, F. (2016). Teacher self-efficacy as a long-term predictor of instructional quality in the classroom. European Journal of Psychology of Education, 31(3), 299-322.

Mohd Kamal H. (2011). Pendidikan Yang Membentuk Syakhsiah Bangsa Dan Proses Islamisasi. Conference paper Kongres Pendidikan Islam Kebangsaan 2011. Anjuran Kementerian Pelajaran Malaysia. Dynasty Hotel Kuala Lumpur, 4-7 Disember.

Mohd K. T. (2010). Kualiti Guru Pendidikan Islam Sekolah Menengah Di Sabah. Thesis. PhD. Universiti Malaysia Sabah.

Narey, M. J. (2019). Who Stands for What Is Right? Teachers' Creative Capacity and Change Agency in the Struggle for Educational Quality. In Creativity Under Duress in Education?(pp. 313-337). Springer, Cham.

Nnebedum, C. (2019). The Value of Integrating 21st Century Skills into the Enterprise of Teaching Sociology.Academic Journal Of Interdisciplinary Studies, 8(1), 37.

Noornajihan J. (2015). Pengaruh Efkasi Kendiri dan Faktor Persekitaran Terhadap Kualiti Guru Pendidikan Islam Sebagai Murabbi. Thesis. PhD. Universiti Kebangsaan Malaysia.

Noornajihan J. (2018). The validity and reliability of self-efficacy instrument for Islamic education teachers. OPCION. 34 (11).

Parker, P. D., Martin, A. J., Colmar, S., \& Liem, G. A. (2012). Teachers' workplace well-being: Exploring a process model of goal orientation, coping behavior, engagement, and burnout. Teaching and Teacher Education, 28(4), 503-513.

Pas, E. T., Bradshaw, C. P. \& Hershfeldt, P. A. (2011). Teacher-and School-Level Predictors of Teacher Efficacy and Burnout: Identifying Potential Areas for Support. Journal of School Psychology

Rimal, K. (2018). Teacher: An Important but Less Recognized Actor of School Curriculum Development in Nepal. Dhaulagiri Journal of Sociology and Anthropology, 12, 66-71.

Runhaar, P., Sanders, K., \& Yang, H. (2010). Stimulating teachers' reflection and feedback asking: An interplay of self-efficacy, learning goal orientation, and transformational leadership. Teaching and Teacher Education, 26(5), 1154-1161.

Schiefele, U., \& Schaffner, E. (2015). Teacher interests, mastery goals, and self-efficacy as predictors of instructional practices and student motivation. Contemporary Educational Psychology, 42, 159-171.

Skaalvik, E. M., \& Skaalvik, S. (2013). Teachers' perceptions of the school goal structure: Relations with teachers' goal orientations, work engagement, and job satisfaction. International Journal of Educational Research, 62, 199-209.

Syed Najmuddin S. H., Ab. Halim T., Isahak O. \& Mohd. Sabri M. (2009). Kajian Persepsi Pelajar Terhadap Tahap Professional Guru Pendidikan Islam MRSM. Journal of Islamic and Arabic Education 1(2): 31-50.

Trentham, L., Silvern, S. \& Brogdon, R. (1985). Teacher Efficacy and Teacher Competency Ratings. Psychology in the Schools, 22(3): 343-352.

Ucar \& Yazici Bozkaya. (2016). Pre-Service Efl Teachers' Self-Efficacy Beliefs, Goal Orientations, And Participations in an Online Learning Environment. Turkish Online Journal of Distance Education-TOJDE, 17 (2) 15-29.

Zhang, M. J., Law, K. S., \& Lin, B. (2016). You think you are big fish in a small pond? Perceived overqualification, goal orientations, and proactivity at work. Journal of Organizational Behavior, 37(1), 61-84. 